\title{
Influence of Calcium Salt Supplementation on Calcium Equilibrium in Skim Milk During pH Cycle
}

\author{
L. S. Canabady-Rochelle, ${ }^{* 1}$ C. Sanchez, ${ }^{*}$ M. Mellema, $†$ A. Bot, $†$ S. Desobry, ${ }^{*}$ and S. Banon* \\ *Nancy-University Laboratoire de Sciences et Gènie Alimentaires, Ecole Nationale Supérieure d'Agronomie et des Industries Alimentaires, \\ 54500 Vandœuvre-Lés-Nancy, France \\ †Unilever Research and Development Vlaardingen, Olivier van Noortlaan 12, 3133 TG Vlaardingen, the Netherlands
}

\begin{abstract}
Calcium is a mineral essential for humans, especially for bone constitution. Yet most of the worldwide population does not satisfy their Ca needs. Hence, Ca supplementation is of major importance, even in western countries where some specific populations at risk do not satisfy the recommended daily intake of Ca. More than $70 \%$ of dietary $\mathrm{Ca}$ comes from dairy products. Calcium supplementation of naturally Ca-rich sources such as skim milk is then of special interest. To our knowledge, few data are available concerning milk Ca (MC) supplementation of milk, particularly when followed by $\mathrm{pH}$ cycle. In this paper, MC supplementation is studied and compared with $\mathrm{Ca}$ chloride (CC) supplementation as a well-known source of Ca. The effect of Ca salt supplementation followed by $\mathrm{pH}$ cycle was studied in reconstituted skim milk. Calcium supplementation was carried out with $\mathrm{CC}$ and $\mathrm{MC}$ at $25 \mathrm{mmol}$ of $\mathrm{Ca} / \mathrm{kg}$ of skim milk. Ionized Ca concentration and turbidity variations were followed in situ by Ca ion selective electrode and turbidimetry using light reflection. From normalized data on ionized Ca concentration and turbidity vs. $\mathrm{pH}$, it appeared that hysteresis areas were smaller for CC-supplemented milk, whereas unsupplemented milk and MC-supplemented milk behaved similarly. For these 3 dairy systems, $\mathrm{pH}$ cycles to $\mathrm{pH} 5.0$ led to a larger hysteresis area than $\mathrm{pH}$ cycles to $\mathrm{pH}$ 5.5. The shrinkage of the hysteresis area could be interpreted as a reinforcement of casein micelles with $\mathrm{Ca}$ ions over the $\mathrm{pH}$ cycle.
\end{abstract}

Key words: calcium supplementation, $\mathrm{pH}$ cycle, skim milk

\section{INTRODUCTION}

Calcium is a mineral essential for humans, particularly during certain phases of life such as growth (for

Received October 12, 2006.

Accepted December 27, 2006.

${ }^{1}$ Corresponding author: Laetitia.Canabady@ensaia.inpl-nancy.fr bone constitution), lactation, and during old age (to act against osteoporosis). According to an INCA survey (Volatier et al., 2000), even in Western countries, specific populations at risk (girls from 10 to $19 \mathrm{yr}$ old, women older than 56, and men older than 65 yr old) do not satisfy the recommended daily intake for Ca. This nutritional deficiency in Ca presents a worldwide health risk and could be overcome by Ca supplementation of food. Dairy products, naturally rich in $\mathrm{Ca}$ and with a high $\mathrm{Ca}$ bioavailability, are appropriate foods for Ca supplementation.

In cow's milk, the mineral fraction represents $9 \%$ (wt/wt) of the average composition. It contains, principally, $\mathrm{Ca}, \mathrm{P}, \mathrm{Mg}, \mathrm{Na}, \mathrm{K}$, and chloride. Milk comprises 2 phases between which minerals are partitioned. Monovalent ions such as $\mathrm{Na}, \mathrm{K}$, and chloride are mostly present in the soluble phase, whereas $\mathrm{Ca}, \mathrm{P}$, and inorganic phosphate are much more present in the colloidal phase. In this latter phase, the so-called CN micelles, $\mathrm{CN}$ are gathered together with minerals, especially with $\mathrm{Ca}$.

The Ca distribution in milk is 2 to 2.5 times higher in the colloidal phase than in the soluble phase (Rajput et al., 1983; De la Fuente, 1998). Additonally, Ca is present in various forms. For a total concentration of $32 \mathrm{~m} M, 22 \mathrm{mM}(69 \%)$ are in the colloidal phase and $10 \mathrm{mM}(31 \%)$ are in the soluble phase. Only $2 \mathrm{~m} M$ of soluble $\mathrm{Ca}$ are free ionic Ca (Walstra and Jenness, 1984). The remainder of soluble Ca is essentially associated to citrate, phosphate, and $\mathrm{CN}$ monomers. In the colloidal phase, Ca can interact with phosphoesters, carboxyl groups of micellar $\mathrm{CN}$, or colloidal phosphate and citrate associated with $\mathrm{CN}$ micelles (Philippe et al., 2003).

When subjected to chemical equilibria, Ca partition in milk varies significantly with physicochemical treatments. Protons and $\mathrm{Ca}$ ions are in equilibria with their respective phosphate and citrate salts (Brulé, 1981). Equilibria are shifted toward the colloidal or the soluble phase, notably as a function of $\mathrm{pH}$, temperature, and Ca salt supplementation. 
During acidification, the ionization state of proteic groups is reduced and involves solubilization of micellar minerals (Dalgleish and Law, 1989). Calcium, Mg, inorganic phosphate, and citrate ions are transferred from the colloidal phase to the soluble phase of milk (Brulé et al., 1974; Dalgleish and Law, 1989; Le Graët and Brulé, 1993; Famelart et al., 1996; Le Graët and Gaucheron, 1999). Calcium phosphate is first solubilized until pH 5.2 (Chaplin, 1984; Le Graët and Brulé, 1993), the $\mathrm{pH}$ value at which all mineral phosphate is solubilized. Then, below $\mathrm{pH}$ 5.2, Ca bound to phosphoserine residues and the carboxyl group is solubilized. At $\mathrm{pH}$ 5.0, almost all the $\mathrm{Ca}$ and inorganic phosphate are present in the soluble phase. Calcium is completely solubilized at pH 3.5 (Van Hooydonk et al., 1986; Law, 1996). Consequently, colloidal mineral solubilization induces dissociation of colloidal $\mathrm{CN}$ monomers during acidification. Moreover, with temperature decrease, the weakening of hydrophobic interactions increases $\mathrm{CN}$ and especially $\beta$-CN (Dziuba and Muzinska, 1998) release from micelles. Up to $60 \%$ of $\mathrm{CN}$ are dissociated at $4^{\circ} \mathrm{C}$ and $\mathrm{pH} 5.2$ (Dalgleish and Law, 1988).

Milk alkalinization involves a reverse effect of acidification; that is, the transfer of minerals from the soluble to the colloidal phase. With $\mathrm{pH}$ increase, inorganic phosphate and Ca decrease in the soluble phase (Van Dijk, 1991, 1992).

With Ca salt supplementation in milk, the ionic environment is modified and minerals equilibrate depending on the Ca salt type used and its concentration as well. Indeed, Ca supplementation induces association of $\mathrm{Ca}$ ions with soluble phosphate and citrate initially present in milk. Consequently, inorganic phosphate and citrate ion concentrations decrease in the aqueous phase (Philippe et al., 2003). Moreover, the former authors observed that supplemented $\mathrm{Ca}$ can absorb into CN micelles. Because of mineral equilibrium modification, $\mathrm{CN}$ micelles undergo physicochemical changes such as hydration and charges decrease and increase of whiteness, turbidity, and hydrophobicity (Philippe et al., 2003).

In this paper, the effect of Ca salt supplementation was studied during the $\mathrm{pH}$ cycle in reconstituted skim milk. Two Ca salts were compared for their distinct physicochemical properties: Ca chloride (CC) for its high solubility and its common use, and milk $\mathrm{Ca}$ (MC) for its potential use as a natural source of Ca for enrichment of dairy products. Indeed, MC is derived from milk and offers a healthy image in labeling. With a good sensorial profile, this Ca source is used in a wide variety of products at relatively high concentrations without causing an off-flavor.

Calcium addition was analyzed in relation to $\mathrm{Ca}$ distribution between the soluble and the colloidal phases and also to the reversibility of phenomena occurring in skim milk subjected to $\mathrm{pH}$ cycle. Two minimal $\mathrm{pH}$ values for $\mathrm{pH}$ cycle were chosen: 5.5 or 5.0. Indeed, this narrow $\mathrm{pH}$ range was reported to be of interest with regard to reversibility in the $\mathrm{CN}$ micellar state (Gastaldi et al., 1996). The experimental setup described in Gaiani et al. (2005) permitted data acquisition in situ of various physicochemical parameters, namely, $\mathrm{pH}$, ionized $\mathrm{Ca}$, and turbidity.

\section{MATERIALS AND METHODS}

\section{Reconstituted Skim Milk Preparation}

Low-heat skim milk powder (Ingredia, Arras, France) was reconstituted at $12 \%$ (wt/wt) in distilled water, stirred for $3 \mathrm{~h}$, and then equilibrated at $4^{\circ} \mathrm{C}$ overnight before use. Reconstituted skim milk powder was used to prevent mineral variations that could falsify results. Two kilograms of reconstituted skim milk was prepared for each experiment.

\section{Ca Supplementation}

Calcium supplementation was performed with $\mathrm{CC}$ $\left(\mathrm{CaCl}_{2} \cdot 2 \mathrm{H}_{2} \mathrm{O}\right.$, analytical grade, Carl Roth $\mathrm{GmbH}$, Karlsruhe, Germany) or MC (Fieldgate natural dairy Ca, First District Association, Litchfield, MN). Milk Ca comprised mainly Ca phosphate and contained 28\% (wt/wt) Ca but also contained other compounds such as lactose and minerals.

Two kilograms of reconstituted skim milk was supplemented with $\mathrm{CC}$ or $\mathrm{MC}$ salts at $25 \mathrm{mmol}$ of $\mathrm{Ca} / \mathrm{kg}$ of skim milk (similar to Guillaume et al., 2002). After a Ca equilibration period ( $2 \mathrm{~h}$ ), supplemented skim milk was subjected to $\mathrm{pH}$ cycle.

\section{pH Cycle Procedure}

Acidification was performed with $\mathrm{HCl}(1 M)$ until reaching a minimal $\mathrm{pH}$ value of $\mathrm{pH} 5.5$ or 5.0. Then, directly after acidification, $\mathrm{NaOH}(1 M)$ was used for a neutralization step. Acid and base were both added to the medium at a rate of $1 \mathrm{~mL} / \mathrm{min}$. Both products were purchased at VWR International (Fontenaysous-Bois, France). The pH cycle was stopped when the initial $\mathrm{pH}$ of the milk was reached $\left(\mathrm{pH}_{\mathrm{i}}=6.65\right)$. The dairy system was thermostated at $4^{\circ} \mathrm{C}$ to minimize aggregation and gelation of proteins.

At the end of each step $\left(\mathrm{T}_{1}=\right.$ probe stabilization; $\mathrm{T}_{2}=$ Ca salt equilibrium; $\mathrm{T}_{3}=$ acidification; and $\mathrm{T}_{4}=$ neutralization), 20-mL samples were taken for further Ca distribution analyses. Duplicate experimental trials were performed. 


\section{Experimental Setup}

Experiments were carried out in a 2 -L vessel equipped with a 4-bladed $45^{\circ}$ impeller (R 100 impeller: $6 \mathrm{~cm}$ in diameter) rotating at $250 \mathrm{rpm}$ (LabMaster mixer, Lightnin, Rochester, NY). The temperature was kept constant at $4^{\circ} \mathrm{C}$ by using a double-walled jacket vessel.

The $\mathrm{pH}$ meter (Radiometer Analytical, Remiremont, France) and $\mathrm{Ca}$ ion selective electrode (Sentek, Braintree, Essex, UK) were immersed into the liquid. A turbidity sensor (Analite NEP 160, McVan Instruments, Mulgrave, Australia) was placed through the vessel wall to avoid disturbances during stirring. This apparatus used light in the near-infrared region (860 $\mathrm{nm}$ ); the incident beam was reflected back at $180^{\circ}$ by any particle in suspension in the fluid to a sensitive electronic receptor. The continuous monitoring (Almemo 8990-8 V5, Ahlborn, Holzkirchen, Germany) of $\mathrm{pH}$, ionized $\mathrm{Ca}$, and turbidity was performed using a data logger coupled with a personal computer equipped with software (AMR WinControl for Almemo). This experimental setup was previously described by Gaiani et al. (2005) in a study on dairy powder rehydration.

\section{Ionized Ca Determination}

Throughout the $\mathrm{pH}$ cycle, the $\mathrm{Ca}$ ion selective electrode measured ionized $\mathrm{Ca}$ concentration through a chemical potential measurement $(\mathrm{mV})$. Calcium activity of calibrating solutions was calculated according to the following equation:

$$
\mathrm{a}_{\mathrm{i}}=\gamma_{\mathrm{i}} \times \mathrm{C}_{\mathrm{i}},
$$

where $\mathrm{a}_{\mathrm{i}}=$ Ca activity $(M) ; \gamma_{\mathrm{i}}=$ activity coefficient (no unit) $=0.40$ for an ionic strength value of $0.1 \mathrm{M}$; and $\mathrm{C}_{\mathrm{i}}=$ ionized $\mathrm{Ca}$ concentration $(M)$.

Ionized $\mathrm{Ca}$ concentrations were then determined from the previous equation, and the dilution effect due to acid and base addition was corrected.

\section{Total and Soluble Ca Determination}

At the end of each step of the kinetics $\left(\mathrm{T}_{1}=\right.$ probe stabilization; $\mathrm{T}_{2}=$ Ca salt equilibrium; $\mathrm{T}_{3}=$ acidification; and $\mathrm{T}_{4}=$ neutralization), total $\mathrm{Ca}$ and soluble Ca were quantified by atomic absorption spectrometry (PerkinElmer, Wellesley, MA) according to the procedure described by Brulé et al. (1974) and Dziuba and Muzinska (1998). A Ca detection lamp was set at a wavelength of $422.7 \mathrm{~nm}$ with a slit of $0.7 \mathrm{~nm}$.

Colloidal and soluble phases of milk were separated by ultracentrifugation (RC M120 GX, Sorvall, Les Ulis,
France) set at $110,000 \times g$ during $1 \mathrm{~h}$ (Dziuba and Muzinska, 1998$)$ at $4^{\circ} \mathrm{C}$. Colloidal Ca was considered as the difference between total $\mathrm{Ca}$ and soluble $\mathrm{Ca}$. Calcium was quantified by atomic absorption in triplicate on duplicate experimental trials.

\section{Statistical Analysis and Normalization Method}

Statistical analysis was performed by using Kyplot freeware. Multiple comparison parametric tests were performed. The same superscript letter was used when no differences between $2 \mathrm{Ca}$ concentrations measured were observed $(P>0.05)$. Statistical analysis was performed independently for the colloidal and the soluble phase.

The min-max normalization method corresponded to the ratio of each value to the maximal value measured during the corresponding experiment.

\section{RESULTS AND DISCUSSION}

\section{Ca Variations as a Function of Time During pH Cycle}

Approximately $1.8 \mathrm{~m} M$ of ionized Ca was measured in skim milk at pH 6.9 and $4^{\circ} \mathrm{C}$, similar to the $2 \mathrm{mM}$ found by Philippe et al. (2003) at $\mathrm{pH} 6.65$ and $25^{\circ} \mathrm{C}$ and in accordance with the low influence of temperature on mineral solubilization (Dalgleish and Law, 1989).

To facilitate comparison between skim milk and $\mathrm{Ca}$ salt-supplemented milks (MC and CC), normalized ionized Ca concentration variations are presented as a function of normalized time in Figure 1. The profiles as a whole can be divided into 3 phases: the stabilization of ionized $\mathrm{Ca}$ after addition of $\mathrm{Ca}$ salts, the increase of ionized $\mathrm{Ca}$ concentration with acidification, and the decrease of ionized Ca concentration with neutralization.

From Figure 1, distinct behaviors can be observed for CC- and MC-supplemented milks. Ionized Ca concentration increased just after CC supplementation, whereas no significant variation occurred with $\mathrm{MC}$ supplementation. In the meantime, $\mathrm{CC}$ addition reduced milk $\mathrm{pH}$ from $\mathrm{pH} 6.9$ to 6.4, displacing protons from proteins. During the stabilization period following salt addition $\left(\mathrm{T}_{1}\right.$ to $\left.\mathrm{T}_{2}\right)$, a decrease in ionized $\mathrm{Ca}$ concentration for CC-supplemented milk was observed from 16 to approximately $13 \mathrm{mM}$. In this period, the ionized $\mathrm{Ca}$ concentration variations in $\mathrm{CC}$ milk could be related to $\mathrm{Ca}$ ion equilibrium between the soluble and colloidal phases of milk. Then, the decrease should correspond either to the formation of complexes with soluble anions (i.e., citrate or phosphate) or to the absorption of $\mathrm{Ca}$ ions into $\mathrm{CN}$ micelles. No variations were observed in the case of $\mathrm{MC}$ addition. Ionized $\mathrm{Ca}$ 

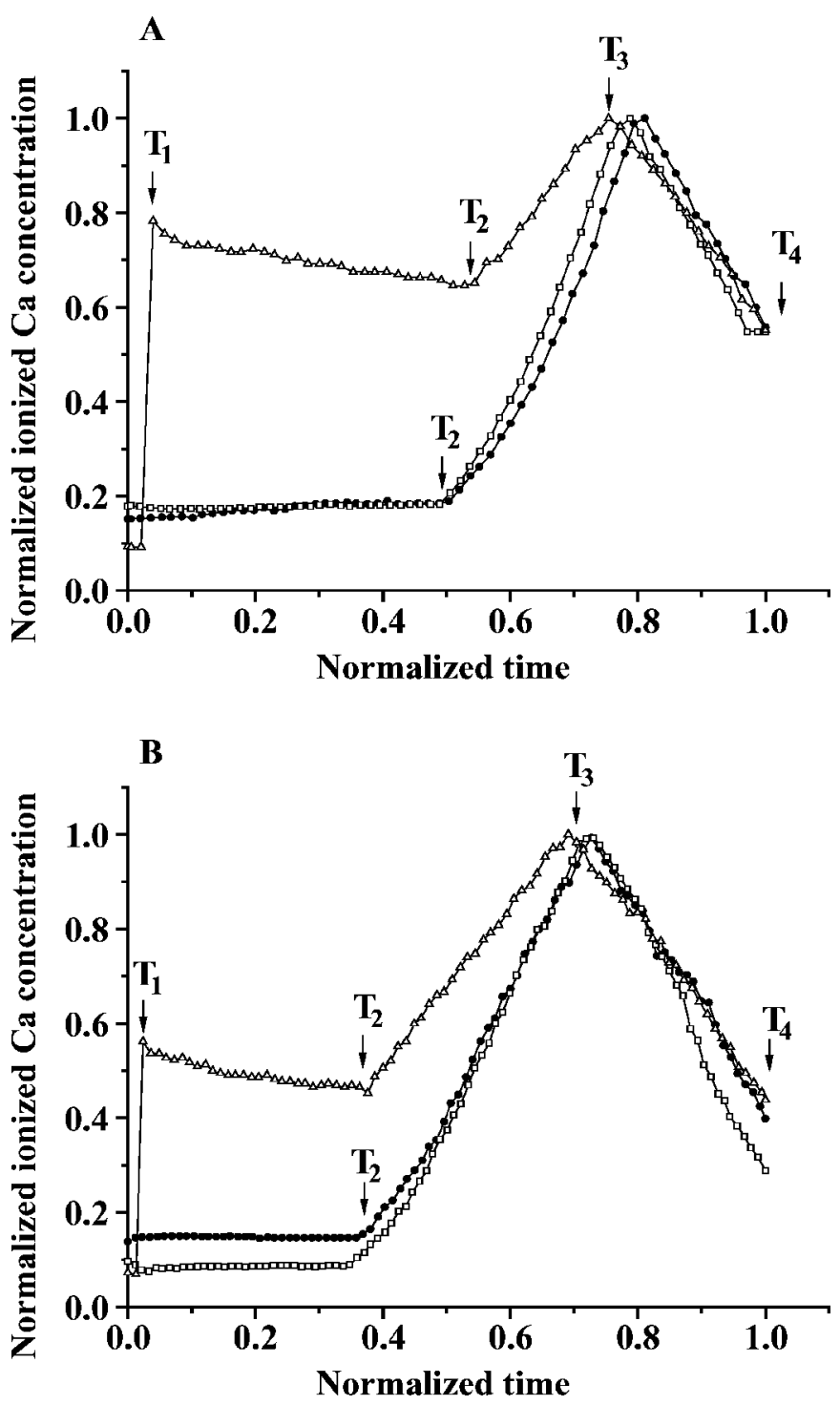

Figure 1. Normalized ionized Ca concentration $(M)$ as a function of normalized time for skim milk (-0-) and for milk Ca-supplemented milk (- $\square-)$ and Ca chloride-supplemented milk (- $\Delta-)$ subjected to $\mathrm{pH}-$ cycle $\left(\mathrm{A}: \mathrm{pH}_{\min } 5.5, \mathrm{~B}: \mathrm{pH}_{\min } 5.0\right) . \mathrm{T}_{1}=$ end of probe stabilization; $\mathrm{T}_{2}=$ end of Ca salt equilibrium; $\mathrm{T}_{3}=$ end of acidification; $\mathrm{T}_{4}=$ end of neutralization.

variations observed after $\mathrm{MC}$ or $\mathrm{CC}$ addition fit with the solubility of $\mathrm{Ca}$ salts commonly reported in the literature, that is, high for CC and poor for MC. Moreover, the experiment performed with pure $\mathrm{Ca}$ phosphate $\left(\mathrm{CaHPO}_{4}, \mathrm{Ca}\right.$ initially present in milk and in MC) showed similar behavior as MC supplementation (results not shown).

For the 3 dairy systems in Figure 1, ionized Ca concentration increased and decreased during acidification $\left(\mathrm{T}_{2}\right.$ to $\left.\mathrm{T}_{3}\right)$ and neutralization $\left(\mathrm{T}_{3}\right.$ to $\left.\mathrm{T}_{4}\right)$, respectively. This reflects the micellar $\mathrm{pH}$-dependent miner- alization described by many authors (Brulé and Fauquant, 1981; Pierre and Brulé, 1981; Chaplin, 1984; Van Hooydonk et al., 1986; Dalgleish and Law, 1989). Calcium ionized during the acidification step may be endogenous (initially present in the colloidal phase before Ca supplementation), exogenous (supplemented $\mathrm{Ca}$ ), or both. During $\mathrm{pH}$ cycles, normalized profiles of ionized Ca vs. time (Figure 1) varied largely and similarly for control and MC milk compared with the lower variations measured for CC milk. During acidification to $\mathrm{pH} 5.5$ and 5.0, up to 80 and $90 \%$ ionized Ca was solubilized for control and MC milk, respectively. In the meantime, 35 to $55 \% \mathrm{Ca}$ was ionized from CC milk. The Ca released from the colloidal phase to the soluble phase (compared with control and MC milk) was reduced. This can be related to the high concentration of ionized $\mathrm{Ca}$ measured in the soluble phase after CC supplementation.

During the neutralization phase, ionized Ca concentration was restored only for $\mathrm{CC}$ milk, indicating the reversibility of $\mathrm{Ca}$ ionization in this dairy system.

The concentrations of soluble and colloidal $\mathrm{Ca}$ are indicated in Tables 1 and 2 for $\mathrm{pH}$ cycle to $\mathrm{pH} 5.5$ and to $\mathrm{pH}$ 5.0, respectively. Colloidal Ca refers either to micellar $\mathrm{Ca}$ or to insoluble $\mathrm{Ca}$ particles. Soluble $\mathrm{Ca}$ represents an ionized form $\left(\mathrm{Ca}^{2+}\right)$ or complexes with anions such as citrate and phosphate. From Tables 1 and 2, the supplementation of MC in milk appeared to correspond to a higher colloidal $\mathrm{Ca}$ concentration compared with CC and skim milk. Because MC solubility was very poor compared with $\mathrm{CC}$, we can expect that a significant amount of $\mathrm{MC}$ powder added in skim milk was still insoluble in the colloidal fraction. Additionally, CC addition was accompanied by an increase in soluble $\mathrm{Ca}$, contrary to skim milk and MC milk. Soluble Ca concentrations were similar for skim and MC milk.

For the 3 dairy systems, pH cycles induced an increase in soluble Ca during acidification (from $\mathrm{T}_{2}$ to $\mathrm{T}_{3}$ ), related mainly to micellar demineralization and a decrease in soluble $\mathrm{Ca}$ during neutralization due to reverse micellar mineralization (from $\mathrm{T}_{3}$ to $\mathrm{T}_{4}$ ). The reversibility of $\mathrm{Ca}$ solubilization was obtained only for CC milk, as it was observed for the ionized Ca fractions in Figure 1.

\section{Comparison of $\mathrm{pH}$-Dependent lonized $\mathrm{Ca}$ Variations as a Function of Ca Salt Type Added}

To point out the influence of $\mathrm{pH}$ on ionized Ca variations, min-max normalized ionized Ca measured during $\mathrm{pH}$ cycles was plotted as a function of $\mathrm{pH}$ (Figure 2).

During acidification and neutralization, normalized ionized Ca concentration increased and decreased, re- 
Table 1. Colloidal and soluble Ca concentrations ( $\mathrm{mmol} / \mathrm{kg}$ ) during milk $\mathrm{pH}$ cycle to $\mathrm{pH} 5.5^{1}$

\begin{tabular}{|c|c|c|c|c|c|c|c|c|}
\hline \multirow[b]{2}{*}{ Item $^{2}$} & \multicolumn{2}{|c|}{$\mathrm{T}_{1}$} & \multicolumn{2}{|c|}{$\mathrm{T}_{2}$} & \multicolumn{2}{|c|}{$\mathrm{T}_{3}$} & \multicolumn{2}{|c|}{$\mathrm{T}_{4}$} \\
\hline & Mean & $\mathrm{SD}$ & Mean & $\mathrm{SD}$ & Mean & $\mathrm{SD}$ & Mean & $\mathrm{SD}$ \\
\hline \multicolumn{9}{|l|}{ Colloidal Ca } \\
\hline Skim milk & $26^{\mathrm{a}}$ & 2 & $25^{\mathrm{ac}}$ & 0.7 & 9 & 5.5 & $18^{\mathrm{cd}}$ & 2.6 \\
\hline MC milk & $24^{\text {ad }}$ & 3 & $48^{\mathrm{b}}$ & 1.3 & $36^{\mathrm{e}}$ & 4.6 & $42^{\text {be }}$ & 2.2 \\
\hline CC milk & $28^{\mathrm{a}}$ & 7 & $42^{\mathrm{be}}$ & 2 & $26^{\text {acd }}$ & 7 & $39^{\mathrm{e}}$ & 4 \\
\hline \multicolumn{9}{|l|}{ Soluble Ca } \\
\hline Skim milk & $10^{\mathrm{f}}$ & 0.6 & $11^{\mathrm{f}}$ & 1 & $25^{\mathrm{g}}$ & 0.4 & $19^{\mathrm{h}}$ & 0.4 \\
\hline MC milk & $10^{\mathrm{f}}$ & 1 & $10^{\mathrm{f}}$ & 0.5 & $23^{\mathrm{g}}$ & 1.7 & $18^{\mathrm{h}}$ & 1 \\
\hline CC milk & $11^{\mathrm{f}}$ & 0.2 & $26^{\mathrm{g}}$ & 4 & 39 & 2 & $24^{\mathrm{g}}$ & 2.7 \\
\hline
\end{tabular}

${ }^{\mathrm{a}-\mathrm{h}}$ The same superscript letter was used when no differences between $2 \mathrm{Ca}$ concentrations measured were observed $(P>0.05)$.

${ }^{1}$ Statistical analysis was performed independently for the colloidal and soluble phases. $\mathrm{T}_{1}=$ end of probe stabilization; $\mathrm{T}_{2}=$ end of Ca salt equilibrium; $\mathrm{T}_{3}=$ end of acidification; $\mathrm{T}_{4}=$ end of neutralization.

${ }^{2} \mathrm{MC}=$ milk Ca-supplemented milk; $\mathrm{CC}=\mathrm{Ca}$ chloride-supplemented milk.

spectively, and a hysteresis phenomenon was observed. Whatever the minimal $\mathrm{pH}$ (i.e., $\mathrm{pH} 5.5$ or 5.0 ), skim milk (Figure 2, panel A) and MC milk (Figure 2, panel B) showed similar trends, contrary to CC milk (Figure 2, panel C). The hysteresis area was reduced for CC milk (Figure 2, panel C), which means that the reversibility of micellar mineral solubilization was better in these conditions. This could be related to the previous capture of Ca cations into the micelles during the equilibrium phase $\left(\mathrm{T}_{1}\right.$ to $\left.\mathrm{T}_{2}\right)$ involving a reinforcement of $\mathrm{CN}$ micelles and then less variation during $\mathrm{pH}$ cycle.

Normalized ionized $\mathrm{Ca}$ plotted vs. $\mathrm{pH}$ profiles for the $2 \mathrm{pH}$ cycles (i.e., to $\mathrm{pH} 5.5$ or 5.0) showed some differences during the neutralization phase. Indeed, for the $\mathrm{pH}$ cycle to $\mathrm{pH} 5.0$, an inflexion point around $\mathrm{pH} 6.0$ to 6.2 was noticeable during neutralization, from which ionized $\mathrm{Ca}$ concentration decreased faster to its initial value. When $\mathrm{pH}$ was decreased to $\mathrm{pH}$ 5.0, $\mathrm{Ca}$ bound to phosphoserines and carboxyl groups of CN (Le Graët and Brulé, 1993) was solubilized in addi- tion to micellar Ca phosphate (as in the case of $\mathrm{pH}$ 5.5). These differences in the nature of $\mathrm{Ca}$ interactions affected during $\mathrm{pH}$ cycles should explain the differences between $\mathrm{pH}$ cycles.

\section{Influence of Salt Nature Supplementation on Turbidity Variation During $\mathrm{pH}$ Cycle}

Normalized turbidity variations plotted as a function of $\mathrm{pH}$ are presented in Figure 3 for the $2 \mathrm{pH}$ cycles. Turbidity variation measured by light reflection can be related to fluctuations in concentration, size, and optical properties of colloidal particles as $\mathrm{CN}$ micelles (Banon and Hardy, 1992). For $\mathrm{pH}$ cycles to $\mathrm{pH} 5.5$ and to $\mathrm{pH} 5.0$, CC milk behaved differently from skim milk and MC milk. First, turbidity increased with CC supplementation in accordance with the observations of Green (1982) and Philippe et al. (2003), who reported a turbidity increase with cationic additives. For CC milk, the decrease of ionized Ca in Figure 2, panel C, is concomitant with the increase of turbidity in Figure

Table 2. Colloidal and soluble Ca concentrations ( $\mathrm{mmol} / \mathrm{kg}$ ) during milk $\mathrm{pH}$ cycle to $\mathrm{pH} 5.0^{1}$

\begin{tabular}{|c|c|c|c|c|c|c|c|c|}
\hline \multirow[b]{2}{*}{ Item $^{2}$} & \multicolumn{2}{|c|}{$\mathrm{T}_{1}$} & \multicolumn{2}{|c|}{$\mathrm{T}_{2}$} & \multicolumn{2}{|c|}{$\mathrm{T}_{3}$} & \multicolumn{2}{|c|}{$\mathrm{T}_{4}$} \\
\hline & Mean & SD & Mean & $\mathrm{SD}$ & Mean & $\mathrm{SD}$ & Mean & $\mathrm{SD}$ \\
\hline \multicolumn{9}{|l|}{ Colloidal $\mathrm{Ca}$} \\
\hline Skim milk & $25^{\text {af }}$ & 1.1 & $27^{\mathrm{ag}}$ & 3 & 2.8 & 0.1 & $12^{\mathrm{c}}$ & 3 \\
\hline MC milk & $27^{\mathrm{a}}$ & 1.6 & $46^{\mathrm{b}}$ & 0.6 & $18^{\mathrm{cf}}$ & 5.2 & $41^{\text {bd }}$ & 2.3 \\
\hline CC milk & $25^{\text {af }}$ & 1.2 & $40^{\text {be }}$ & 3.8 & $19^{\text {ac }}$ & 11.7 & $35^{\text {deg }}$ & 2 \\
\hline \multicolumn{9}{|l|}{ Soluble $\mathrm{Ca}$} \\
\hline Skim milk & $11^{\mathrm{h}}$ & 0.5 & $11^{\mathrm{h}}$ & 0.7 & $34^{\mathrm{i}}$ & 1.5 & $24^{\mathrm{k}}$ & 2.3 \\
\hline MC milk & $11^{\mathrm{h}}$ & 0.5 & $11^{\mathrm{h}}$ & 0.2 & $37^{\mathrm{ij}}$ & 1.8 & $20^{\mathrm{k}}$ & 0.5 \\
\hline CC milk & $11^{\mathrm{h}}$ & 1.1 & $26^{\mathrm{k}}$ & 0.4 & $40^{\mathrm{j}}$ & 10 & $25^{\mathrm{k}}$ & 0.7 \\
\hline
\end{tabular}

${ }^{\mathrm{a}-\mathrm{k}}$ The same superscript letter was used when no differences between $2 \mathrm{Ca}$ concentrations measured were observed $(P>0.05)$.

${ }^{1}$ Statistical analysis was performed independently for the colloidal and soluble phases. $\mathrm{T}_{1}=$ end of probe stabilization; $\mathrm{T}_{2}=$ end of Ca salt equilibrium; $\mathrm{T}_{3}=$ end of acidification; $\mathrm{T}_{4}=$ end of neutralization.

${ }^{2} \mathrm{MC}=$ milk Ca-supplemented milk; $\mathrm{CC}=\mathrm{Ca}$ chloride-supplemented milk. 

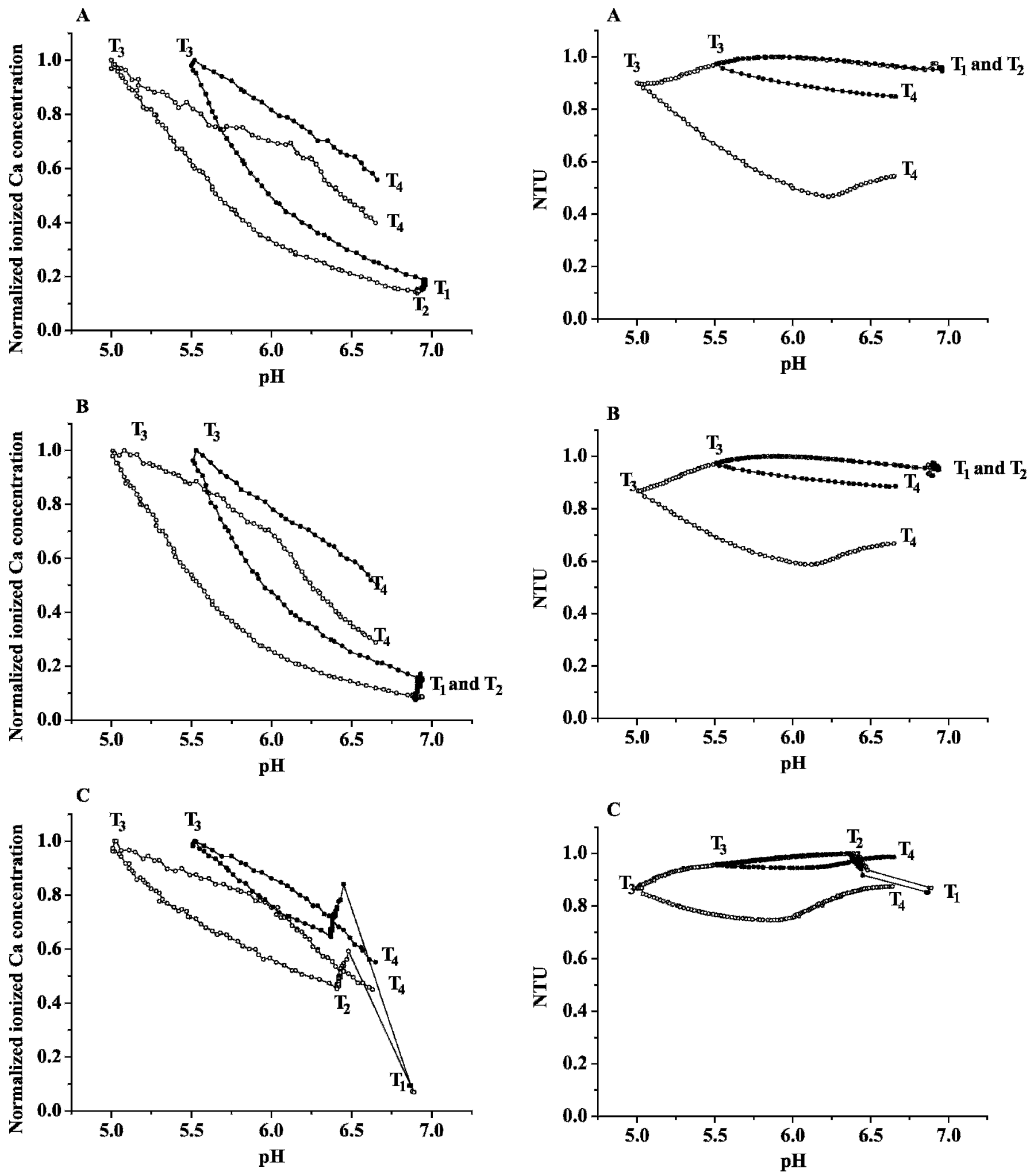

Figure 2. Min-max normalized ionized Ca measured during $\mathrm{pH}$ cycles as a function of $\mathrm{pH}$ (A: skim milk; B: milk Ca-supplemented milk; $\mathrm{C}$ : Ca chloride-supplemented milk). $-\bigcirc-: \mathrm{pH}_{\min }=5.0$;-๑-: $\mathrm{pH}_{\min }=$ 5.5. $\mathrm{T}_{1}=$ end of probe stabilization; $\mathrm{T}_{2}=$ end of $\mathrm{Ca}$ salt equilibrium; $\mathrm{T}_{3}=$ end of acidification; $\mathrm{T}_{4}=$ end of neutralization.

Figure 3. Min-max normalized turbidity (NTU) as a function of pH (A: skim milk; B: milk Ca-supplemented milk; C: Ca chloridesupplemented milk). - $-: \mathrm{pH}_{\min }=5.0 ;-\boldsymbol{-}_{-}: \mathrm{pH}_{\min }=5.5$. $\mathrm{T}_{1}=$ end of probe stabilization; $\mathrm{T}_{2}=$ end of $\mathrm{Ca}$ salt equilibrium; $\mathrm{T}_{3}=$ end of acidification; $\mathrm{T}_{4}=$ end of neutralization. 
3 , panel $\mathrm{C}$, and then could reflect the reinforcement of micellar structure. From the variation of other parameters (milk lightness increase, average diameter constant, and hydrodynamic diameter constant), Philippe et al. (2005) related the turbidity increase to a micellar density increase.

During acidification, the 3 dairy systems (Figure 3 ) showed a similar slight turbidity variation from initial $\mathrm{pH} 6.9$ up to $\mathrm{pH}$ 5.0, which could be related to micellar material loss; that is, minerals and CN (Dalgleish and Law, 1988, 1989), and consecutive variations in the voluminosity and size of CN micelles (Snoeren et al., 1984; Banon and Hardy, 1991). During neutralization, turbidity variations are larger than during acidification and should reflect an important restructuring of the colloidal phase.

The $\mathrm{pH}$ cycle to $\mathrm{pH} 5.0$ amplified the differences between the acidification and neutralization phases, and hysteresis areas were then larger for all dairy systems. These differences should reflect the extent of micellar CN solubilization during acidification (Rose, 1968; Downey and Murphy, 1970; Creamer et al., 1977; Dalgleish and Law, 1988) and the micellar components' ability to newly interact during neutralization. Hysteresis areas were systematically smaller for CC milk and almost similar for MC and skim milks. This could be attributed to the initial reinforcement of $\mathrm{CN}$ micelles by $\mathrm{CC}$ addition related to the diffusion of ionized $\mathrm{Ca}$ into the micelle.

Compared with $\mathrm{pH} 5.5$, acidification to $\mathrm{pH} 5.0$ modified the behavior of $\mathrm{MC}$ and skim milks during neutralization and the same behavior was observed with $\mathrm{CC}$ milk, that is, turbidity decreased drastically to about $\mathrm{pH} 6.1$ to 6.25 then increased to the final $\mathrm{pH} 6.65$ (Figure 3). The minimal value of turbidity at around $\mathrm{pH} 6.0$ to 6.2 was consistent with the inflexion point observed on ionized Ca vs. pH curves in the neutralization phase (Figure 2). This could be related to the reincorporation, via $\mathrm{Ca}$ interactions, of $\mathrm{CN}$ monomers solubilized during acidification (Dalgleish and Law, 1989).

\section{CONCLUSIONS}

In this paper, the influence of Ca salt supplementation on Ca equilibrium was studied in skim milk during the $\mathrm{pH}$ cycle at $4^{\circ} \mathrm{C}$. Compared with highly soluble CC, MC salt had few effects on Ca equilibrium in milk.

According to ionized $\mathrm{Ca}$ and turbidity measurements, CC supplementation would favor the reinforcement of micellar structure and reduce the micellar dissociation during the $\mathrm{pH}$ cycle at $4^{\circ} \mathrm{C}$.

Further studies on the structure and physicochemical properties of $\mathrm{CN}$ micelles after Ca salt supplemen- tation are necessary to improve the comprehension of Ca-CN micelle interactions and of their stability during technological treatments.

\section{ACKNOWLEDGMENTS}

We thank Unilever Research and Development Center of Vlaardingen for their scientific and financial support. Thanks to Carole Jeandel for helpful technical assistance.

\section{REFERENCES}

Banon, S., and J. Hardy. 1991. Study of acid milk coagulation by an optical method using light reflection. J. Dairy Res. 58:75-84.

Banon, S., and J. Hardy. 1992. A colloidal approach of milk acidification by glucono- $\delta$ lactone. J. Dairy Sci. 75:935-941.

Brulé, G. 1981. Les minéraux du lait. Rev. Lait Fr. 400:61-65.

Brulé, G., and J. Fauquant. 1981. Mineral balance in skim-milk and milk retentate: Effect of physicochemical characteristics of the aqueous phase. J. Dairy Res. 48:91-97.

Brulé, G., J. L. Maubois, and J. Fauquant. 1974. Etude de la teneur en éléments minéraux des produits obtenus lors de l'ultrafiltration du lait sur membrane. Lait 54:600-615.

Chaplin, L. C. 1984. Studies of micellar calcium phosphate: Composition and apparent solubility product in milk over a wide $\mathrm{pH}$ range. J. Dairy Res. 51:251-257.

Creamer, L. K., G. P. Berry, and O. E. Mills. 1977. A study of the dissociation of $\beta$-casein from the bovin casein micelle at low temperature. N. Z. J. Dairy Sci. Technol. 12:58-66.

Dalgleish, D. G., and A. J. Law. 1988. pH-Induced dissociation of bovine casein micelles. I. Analysis of liberated caseins. J. Dairy Res. 55:529-538.

Dalgleish, D. G., and A. J. Law. 1989. pH-Induced dissociation of bovine casein micelles. II. Mineral solubilization and its relation to casein release. J. Dairy Res. 56:727-735.

De la Fuente, M. 1998. Changes in the mineral balance of milk submitted to technological treatment. Trends Food Sci. Technol. 9:281-288.

Downey, W. K., and R. F. Murphy. 1970. The temperature-dependent dissociation of $\beta$-casein from bovine casein micelles and complexes. J. Dairy Sci. 37:361-372.

Dziuba, J., and B. Muzinska. 1998. An effect of the low-temperature induced processes of dissociation-association on the molecular state of casein. Milchwissenschaft 53:551-555.

Famelart, M. H., F. Lepesant, F. Gaucheron, Y. Le Graët, and P. Schuck. 1996. pH-Induced physicochemical modifications of native phosphocaseinate suspensions: Influence of aqueous phase. Lait 76:445-460.

Gaiani, C., S. Banon, J. Scher, P. Schuck, and J. Hardy. 2005. Use of turbidity sensor to characterize micellar casein powder rehydration: Influence of some technological effects. J. Dairy Sci. 88:2700-2706.

Gastaldi, E., A. Lagaude, and B. Tarodo de la Fuente. 1996. Micellar transition state in casein between $\mathrm{pH} 5.5$ and 5.0. J. Food Sci. 61:59-64.

Green, M. L. 1982. Effect on the composition and properties of casein micelles of interaction with ionic material. J. Dairy Res. 49:87-98.

Guillaume, C., S. Marchesseau, A. Lagaude, and J. L. Cuq. 2002. Effect of salt addition on the micellar composition of milk subjected to $\mathrm{pH}$ reversible $\mathrm{CO}_{2}$ acidification. J. Dairy Sci. 85:2098-2105.

Law, A. J. 1996. Effects of heat treatment and acidification on the dissociation of bovin casein micelle. J. Dairy Res. 63:35-48.

Le Graët, Y., and G. Brulé. 1993. Les équilibres minéraux du lait: Influence du pH et de la force ionique. Lait 73:51-60. 
Le Graët, Y., and F. Gaucheron. 1999. pH-Induced solubilisation of minerals from casein micelles: Influence of casein concentration and ionic strength. J. Dairy Res. 66:215-224.

Philippe, M., F. Gaucheron, Y. Le Graët, F. Michel, and A. Garem. 2003. Physicochemical characterisation of calcium-supplemented skim milk. Lait 83:45-59.

Philippe, M., Y. Le Graët, and F. Gaucheron. 2005. The effects of different cations on the physicochemical characteristics of casein micelles. Food Chem. 90:673-683.

Pierre, A., and G. Brulé. 1981. Mineral and protein equilibria between the colloidal and soluble phases of milk at low temperature. J. Dairy Res. 48:417-428.

Rajput, Y. S., M. K. Bhavadasan, and N. C. Ganguli. 1983. Changes in the chemical status of calcium in casein micelles with the $\mathrm{pH}$ of milk. Milchwissenschaft 38:211-213.

Rose, D. 1968. Relation between micellar and serum casein in bovine milk. J. Dairy Sci. 51:1897-1902.
Snoeren, T. H., H. J. Klok, A. C. van Hooydonk, and A. J. Damman. 1984. The voluminosity of casein micelles. Milchwissenschaft 39:461-463.

Van Dijk, H. J. 1991. The properties of casein micelles. 4. The effect of the addition of $\mathrm{NaCl}, \mathrm{MgCl}_{2}$ or $\mathrm{NaOH}$ on the partition of $\mathrm{Ca}$, $\mathrm{Mg}$ and $\mathrm{PO}_{4}$ in cow's milk. Neth. Milk Dairy J. 45:241-251.

Van Dijk, H. J. 1992. The properties of casein micelles. 6. Behavior above $\mathrm{pH} \mathrm{9,} \mathrm{and} \mathrm{implications} \mathrm{for} \mathrm{the} \mathrm{micelle} \mathrm{model.} \mathrm{Neth.} \mathrm{Milk}$ Dairy J. 46:101-113.

Van Hooydonk, A. C., H. G. Hagedoorn, and I. J. Boerrigter. 1986. $\mathrm{pH}$-Induced physico-chemical changes of casein micelles in milk and their effect on renneting. 1. Effect of acidification on physicochemical properties. Neth. Milk Dairy J. 40:281-296.

Volatier, J. L., J. Maffre, and A. Couvreur. 2000. Enquête individuelle et nationale sur les consommations alimentaires (INCA). Technique et Documentation-Lavoisier, Paris, France.

Walstra, P., and R. Jenness. 1984. Dairy Chemistry and Physics. John Wiley and Sons, New York, NY. 